\title{
FASHION INDUSTRY AS A REPRESENTATIVE SPACE OF HUMAN BEING
}

\author{
Gaznyuk L. M., Semenova Yu. A.
}

\section{INTRODUCTION}

All forms of presentation of fashion discourse are associated with the becoming and formation of the fashion infrastructure, and the fashion industry implements an original synthesis of art, industry and technology. The postmodern intentions of fashion present the artistry of postmodern cultural practices. Fashion transforms the implications of a person's selfidentity in the context of sociocultural space, which turn into an original art business, into a total artifact of reality, where fashion from haute couture smoothly transforms into prêt-a-porter, and prêt-a-porter fashion transforms into functional fashion. Prêt-a-porter forms its figurative thesaurus in the space of reduced fashion haute couture and decorative coloring of the functional fashion. Fashion as a presentational space exists as allusions, inserts, ontology fragments produced in art reservations, art presentations, model designs. An important aspect of the specifics of the functioning of the modern fashion industry is the combination of hi-tech and ethnocultural coloring, taking into account the emancipating potential of this space to represent your own personality and confirm your unique style.

\section{Fashion as a cultural practice}

Fashion as a cultural practice is a rather deep, archaic type of cultural creativity. There are many motivations and intentions in the fashion space, the main of which are the development of cultural patterns and social standards for imitation. They are organically supplemented by a noncoercive, freely expressed desire of fashion industry consumers to use the possibilities of fashion tools to present their own personality. Social regulation and control are the primary functions of the fashion industry, which for centuries has provided society with markers for determining gender and profession, age, economic and class status, worldview and even individual mood. According to Michel Foucault's definitions, fashion is one of the disciplinary practices which purpose is to award the recipient with attributes of the sign system to which he belongs, or seeks to belong. The 
history of the costume illustrates functional regulation, marking the status of a person with his clothing. In his day, the English king Edward III initiated a ban on the use of ermine fur by all sectors of society, except the royal family ${ }^{1}$; the specific design of costumes of European medieval prostitutes in the XIV-XV centuries is also known (black and white hat for Strasbourg, red bow on the sleeve for Besancons, a veil with a green stripe two fingers wide for Augsburg people ${ }^{2}$, as well as the widespread use of wooden klomps exclusively among the poor in Dutch society. Today, clothing continues to be part of social being providing the individual with a sense of safe conformity and compliance with social expectations that is especially clearly seen in everyday life dress codes for most life situations and events of varying degrees of dogmatism, the non-observance of which generates the feeling of shame for violating generally accepted standards.

A significantly higher level of social pressure from violation of established norms is assigned to female representatives in modern society, for whom the requirements of "normal" and "appropriate" type of clothes are fuzzy and blurry. In particular, the borderlines between the clothes of a confident woman who loves and is proud of her body, and a woman in a seductive costume that "deliberately provokes men to sexual abuse", or the difference between the outfits of a successful, emancipated woman, in whose wardrobe "masculine" items like men's shirts and trousers predominate, and a woman whose image is defined as a "blue stocking" is bizarrely vague and depend solely on pressing problems of public opinion to condemn or support the choice of a particular individual.

An exact explanation of the reasons for the existence of gender asymmetry in fashion space is presented by Australian researcher Robin Cooper: "Until the beginning of the 19th century, men and women followed fashion trends equally. However, in the 19th century, fashion and femininity significantly, but not completely replaced men from this sphere. "Not completely," since a man's suit could not exist outside of fashion, although its transformations were slower and not so amazing. Today, considering that appearance plays such an important role in human life, men are more involved in fashion, but still not at the same level as women. Fashion is not just the prerogative of women, fashion is a woman, it is she, not he" ${ }^{3}$. In

${ }^{1}$ Ermine / Encyclopedia Britannica. URL: https://www.britannica.com/animal/ ermine-mammal

${ }^{2}$ Блох И. История проституции. URL: http://lib.rus.ec/b/111358/read

${ }^{3}$ Cooper R. Fashion and feminism. Australian Feminist Studies. 1987. №. 2: 4. P. 166. 
addition, a thorough study of the history of women's clothing will certainly illuminate specific methods of inculcating normative femininity to female objectified bodies with a patriarchal power order. In his work "Indirect speech and voices of silence" M. Merleau-Ponty draws attention to the influence of high-heeled shoes on the formation of differences between female and male bodily experiences: "A woman walking by [...] is a special way of flesh being that can be traced in walking, and even in the pressure of the heels on the ground [...], which is a noticeable variation of the norm of walking, personal appearance, touching, speaking, which I realize thanks to my body" 4 .

There are many examples in the history of women's costumes, the purpose of which was to create physical discomfort for the female body and to cultivate behavioral inclinations to embody such qualities of normative femininity as seduction, passivity and limited physical mobility. In particular, at the beginning of the 20th century, the symbol of a woman's subordinate position in society was a suit with long skirts and trains, with a corset, crinoline or tournures, which did not provide opportunities for active movement and was logically contrasted with comfortable, rational men's clothing, suitable for an energetic lifestyle. "[...] feminists proposed, first of all, to reform the women's costume. For this, it is necessary to borrow from a men's suit, first of all, trousers, as well as practical materials. The French writer Georges Sand began the first in the XIX century to wear a men's suit. An American Amelia Bloomer, state Ohio, in 1881 proposed replacing a dress with a long crinoline and corset with a dress with a knee-length skirt, which had to be worn with long trousers" $"$. We find similar ideas in Joan Entwistle, who notes that "according to many feminists, a corset is a piece of clothing, disciplines the female body and makes it "obedient", submissive, like an "exquisite slave" ${ }^{\text {. }}$. No less uncomfortable, but much more dangerous can be considered the tandem of the Amazon, a women's riding suit, an integral part of which was a corset and a long skirt, and a female saddle in which the rider's legs are on the left side of the horse, and do not cover on both sides. Such a strictly regulated way of riding women was founded by Princess Anna Bohemia in 1382 during her trip to Europe to her fiance Richard II in order to preserve the virginity of the future queen, and existed

${ }^{4}$ Merleau-Ponty M. Indirect Language and the Voices of Silence. Merleau-Ponty Reader. Evanston, IL : Northwestern UP, 2007. P. 255.

${ }^{5}$ Ермилова Д.Ю. История домов моды. Москва : Академия, 2003. С. 21.

${ }^{6}$ Entwistle J. The Dressed Body. Body Dressing. Oxford, New York : Berg, 2001. P. 41. 
until the 1930s, justifying her vitality by caring for women's health and their morality ${ }^{7}$. It is worthy of note that the Amazon costume, as the only acceptable suit for a horsewoman, is designed to emphasize her femininity, a slender figure and attractiveness, and not to make the movement convenient and safe, which often led to injuries of the rider: "The skirt could get tangled between her legs, or catch on the saddle bow during her fall, due to which the horse at high speed dragged the rider on the ground and could even trample her" ${ }^{\prime \prime}$. The feminist movement and emancipation of the early twentieth century created the prerequisites for the liberation of the female body from the clutches of a patriarchal costume, destined to reproduce the image of femininity conforming to modern life, and the emergence of a new clothing concept, corresponding to the lifestyle of the "new woman". However, a further retrospective analysis of the twentieth-century fashion discourse demonstrates a permanent opposition to the trends of liberation and correction of a woman's figure through clothes. So, the Parisian fashion designer Paul Poiret, having freed woman in 1906-1907 from the pressure of the corset, created the first prototype of a pencil skirt, it is still considered the most feminine and sexy item of a woman's wardrobe, "he "tied" her [woman] legs with skirts that "limp", which appeared in 1910. These were narrow straight skirts or narrowed skirts to the bottom, in which it could only be walked in small steps, since cuttings were not allowed" ${ }^{\text {. We can consider }}$ Christian Dior to be an ideological follower of P. Poiret, who not only introduced a pencil skirt into widespread consumption, but also invented the "new look" silhouette, which became the quintessence of femininity, that was lost in masculinity and functional fashion of the first half of the $20^{\text {th }}$ century. The image of a woman, developed by Chr. Dior, is based on such qualities as fragility, tenderness, mystery, complemented by sexuality, outlined by a full breast, an extremely narrow waist and rounded hips. The silhouette is depicted using a corset, a bra, guepiere (belt for tightening the waist) and a belt for stockings, fitting the female body to the required volumes and shapes. "The pads were set in hips in Dior's models, stiff underskirts, whalebone plates and cup linings were sewn in. Dior's clients agreed to such voluntary torture, as these dresses were created in order to decorate a woman" $"$. However, the popularity of the image invented by

7 Johnson B. Riding Side-Saddle. Historic UK. URL: http://www.historicuk.com/CultureUK/Riding-SideSaddle/

${ }^{8}$ David A.M. Elegant Amazons: Victorian Riding Habits and the Fashionable Horsewoman. Victorian Literature and Culture. 2002. Vol. 30. № 1. P. 185.

${ }^{9}$ Ермилова Д. Ю. История домов моды. Москва : Академия, 2003. С. 32.

${ }^{10}$ Ibid. C. 107. 
Chr. Dior did not last long, losing clients' commitment not only to the inconvenience and high cost of "new look" outfits, but also to its ideological program, which provided for an exclusively decorative existence for a woman in the roles of a wife and mother assigned to her, restrictions of which the representatives of the second wave of feminism actively spoke. The next milestone event for the transformation of femininity in the twentieth-century fashion discourse was a 1968 protest by American feminists during the Miss America contest in Atlantic City, New Jersey. Speaking against the objectification of women by beauty contests, protesters threw attributes of patriarchal oppression into the garbage container, including high-heeled shoes and bras. This event caused a loud resonance in the media and was later mythologized to the level of "burning bras" by militant feminists. Activity of representatives of American second wave feminism concerning public exemption from underwear, what was served to provide the female body socially accepted forms, became precedent in the deconstruction of generally accepted ideas about instilling femininity in women with fashion.

It is fair to say that modern men also often feel discomfort from being forced to wear clothes, dogmatically matching the dress code, but it does not take into account the physiological needs of a person. In particular, the situation with the mass discontent of men in a number of European countries at the beginning of the hot summer of 2017 is indicative; it was brightly treated in the media. A significant number of office workers and public transport drivers whose dress code stipulated a ban on staying in the workplace in shorts, which unlike trousers provide partial cooling of the body at high temperatures, chose to attend work in women's skirts, thus protesting against gender discrimination in dress code.

The cultural practices of fashion are presented through the image of a mannequin, which, by its functional purpose, is a suffering substance, silently undergoing the transformations and changes to which it is subjected without manifesting reactions and meekly accepting physical pain from needles and pins.

In addition, due to its passive and subordinate position, the mannequin acquires a pronounced feminine character and female reality, being the ideal embodiment of femininity relatively to fashion - an object dressed according to the latest trends without a voice and the right to choose: "the body, especially the female, and to a greater extent the body of absolute model, what is a mannequin, is constituted as an object corresponding to other objects deprived of sexuality functional objects that are informed by 
advertising" ". According to the Australian researcher Kim Toffoletti, the mannequin is a symbol of the intersection of the problems of consumerism, femininity and feminism, representing a role model for women, who automatically identify themselves with the image that reproduces the mannequin ${ }^{12}$. In addition, this attribute of tailor's art personifies a reduced female body; it can be modified in accordance with the wishes of the master and customer. The location of the mannequin in the public space of the storefront returns us to the eternal positioning of a woman as an object of sight.

The appealing to the image of the mannequin is characteristic of the work of artists of the second half of the twentieth century, whose heritage is more or less feminist. In particular, Yayoi Kusama in her environmental work "From the Driving Image Show" (1964) and Marina Abramovic in her action "Art must be beautiful, the artist must be beautiful" sharply problematized the image of the mannequin, comprehending the adaptation of the beauty ideals produced by men for women, which are symbolized by a mannequin $^{13}$.

\section{Fashion industry as the basis of gender identity}

Considering the question of the origins and mechanisms of inculcating normative femininity in women and the disciplinary nature of the fashion industry, special attention is required to the problem of juvenilization as a symptom of fashion discourse and a specific strategy for the implementation of femininity. Juvenilization means "rejuvenation of an individual's behavioral strategies, realized by including behavioral models conventionally recognized inherent in young people. Juvenilization means any "shift" in behavioral strategies to patterns inherent in the younger generation" $"$. One of the practices for implementing the juvenile trend, in addition to using products created for children and adolescents (computer games, comics, cartoons, food, etc.), is external likening to children, which differs significantly from various rituals of "rejuvenation". We are talking

${ }^{11}$ Бодрийяр Ж. Общество потребления. Его мифы и структуры ; пер. с. фр. Е.А. Самарской. Москва : Республика; Культурная революция, 2006. С. 174.

12 Toffoletti K. Cyborgs and Barbie Dolls: Feminism, Popular Culture and the Posthuman Body. London : IB Tauris, 2007. P. 65.

${ }^{13}$ Robinson H. Feminism Art Theory: An Anthology 1968 - 2014. London : Wiley Blackwell, 2015. P. 350.

14 Манокин М.А. Ювенилизация современного общества: культурологические аспекты. Общество. Среда. Развитие (Terra Humana). 2012. № 3. C. 77. 
about such fashion trends of recent years as the use of all shades of pink in clothes; infantilization of a woman's costume by adding bows, frills, floral patterns, not serious inscriptions and prints; creation of accessory allusions to children's toys, as well as makeup in the style of baby look. It is noteworthy that juvenile appearances are more characteristic of women as consumers of fashion industry products, due to the growing stylistic popularity of youthful femininity. The flip side of juvenile femininity is the excessive sexualization of childhood, as an extreme consequence of the described cultural phenomenon. Given the fact that fashion is an important social institution that determines a significant share of the values, scenarios, and behaviors of a gender-schematized society, one of the important functions of this structure is to facilitate the adaptation of the child to the existing "male - female" dichotomy with certain characteristics for each component and their opposition, with its inherent temporal variability. However, in addition to education, understanding the cultural differences between the sexes, the commercial component of the fashion industry causes such a psychological phenomenon as faster growing up of children (KGOY - "Kids Getting Older Younger"), in which a child reproduces behavioral patterns inherent in adults and not suitable for his physiological development, caused by media sexualization of childhood and the growing attractiveness of children as a valuable market segment of consumers. The consequence of such accelerated growing up is not only the general disorientation of the child, problems in adaptation and communication with peers, but also "tiredness from the world, cynicism, lack of interest in cognition" ${ }^{15}$, as well as the infantilization of adults that these children later become (KSYL - "Kids Are Staying Younger Longer"). Today, the tradition of representing girls as "little women" with the corresponding external attributes of adulthood is preserved in numerous fashionable practices, among which we list the following: making such excessively sexy dolls as Barbie, Bratz, Monster High, Winx with hypertrophied narrow waists, long legs, full lips and big eyes in seductive garbs; distribution of play sets of bright cosmetics and jewelry, often complemented by high-heeled shoes, among which we especially note the trend of the last two years - baby's bootees with heels. Baby's bootees with decorative heels for babies under 6 months of age are in regular children's collections of such fashion houses as Lanvin, Marc Jacobs, Dolce \& Gabbana, Jean Paul Gaultier, Fendi, Gucci, Burberry,

15 Linn S. A Royal Juggernaut: The Disney Princesses and Other Commercialized Threats to Creative Play and the Path to Self-Realization for Young Girls. The Sexualization of Childhood. Westport, Connecticut, London : Praeger, 2009. P. 47. 
which in design and price are often not inferior to adult clothing lines. Separately it is necessary to highlight such a cultural phenomenon as children's beauty contests, focused more on girls than on men. It is expected that a characteristic feature of such events is the sexualization of children, which is manifested in "reduced copies of adult women's clothes, which are dressed in little girls, applying makeup by professional makeup artists, using sunless tanning for the skin, coloring and hair extensions, and the use of provocative poses that are more appropriate for adults models" ${ }^{\prime \prime 6}$. Imitation of hypertrophic images of femininity by girls at the age of physical and mental immaturity leads to complex consequences, including eating disorders, problems with self-esteem, obsessive orientation to physical attractiveness ${ }^{17}$.

Attracts interest the practice of child femininity imitation, presented by American media and body politics researcher Gigi Durham in her work "The Lolita Effect" (2008), by the name of which there is an understanding of the new phenomenon of a playful, seductive girl aged 9 to 14 years, freely and readily affirms her sexuality, whose normative image is produced by the media style for a commercial purpose. The harmful influence of the media on the formation of sexualized images of children is noted: "Instead of offering girls and the rest of the audience a thoughtful, impartial, progressive and ethical understanding of sexuality, our media and culture represent "prostitutes"- hypersexual girls. This is the Lolita effect"18. Among the social consequences, the dominance in the information space of the images of young "Lolitas" J. Durham notes the following: decreasing the age of first sexual contact, increasing the number of cases of eating disorders, early pregnancies, sexual transmission of infections, including HIV/AIDS ${ }^{19}$. Also, J. Durham identified five myths about child sexuality that are actively circulated in modern culture:

1) "If you are this, show it" - coercion to manifest sexuality from an early age: "girls as the target media audience realize that sex is important, social success requires being desired, jokes and awareness of the topic of sex

${ }^{16}$ Wiehe VR Nothing pretty in child pageants. Lexington Herald Leader. URL: http://www.kentucky.com/opinion/op-ed/article44120718.html

17 Cartwright MM Child Beauty Pageants: What Are We Teaching Our Girls? Psychology Today. URL: https://www.psychologytoday.com/blog/food-thought/ 201108/child-beauty-pageants-what-are-we-teaching-our-girls

${ }^{18}$ Durham G.M. The Lolita Effect: The Media Sexualization of Young Girls and What We Can Do About It. Woodstock \& New York : The Overlook Press, 2008. P. 27.

${ }^{19}$ Ibid. P. 202 
provide benefits, and recognizing you as "hot" is the biggest recognition for a girl" 20 .

2) "Anatomy of the sex goddess" - Barbie's recognition of the ideal of female beauty: "Too thin to stand upright, she symbolizes the perfect girl's body, a model for

all races, classes and nationalities" 21 .

3). "Pretty babies" - the age of girls who are recognized as sexually desirable, and by which the readiness for sexual relations is fixed, is becoming less and less, provoking the question of "age of consent", physiological readiness for intimacy, child pornography and sexual violence.

4). "Violence is sexual" - legitimization of manifestations of violence and cruelty in sexual relations: "It is important to recognize that the use of sexual violence against girls, represented by media channels, illuminates and reinforces the existing system of abuse" 22 .

5). "What guys like" - the assertion of the notion that "the sexual community belongs to men, and women survive by restraining themselves, as well as adapting and subordinating to male desires"23.

We can consider the cult series of photographs "Kids" (2000) by Sergey Bratkov as a symptomatic illustration of the sexualization of children in the fashion space, each exposition of which provokes dissatisfaction of the audience and a heated discussion about the boundaries between contemporary art and pedophilia. This series of photographs appeared as a result of an agreement between the Kharkov social-critical artist and his acquaintances, who asked him to take some photos of their children for a portfolio for modeling agencies. The collaboration resulted in images of brightly painted children in "adult" poses (smoking a cigarette, seductive licking of a candy, with a plastic cup in his hand and eyes closed) opposite the beggar interior of the apartment. Interpretation of the series "Kids" will certainly lead to a reflection on the responsibility of parents for the conscious formation of the value orientation of children on physicality and sexuality: "kids" can be perceived as an ironic attempt to rethink the norms of beauty and patterns of behavior accepted in society" ${ }^{24}$. Analyzing the specifics of

${ }^{20}$ Ibid. P. 67.

${ }^{21}$ Durham G.M. The Lolita Effect: The Media Sexualization of Young Girls and What We Can Do About It. Woodstock \& New York : The Overlook Press, 2008. P. 96.

${ }^{22}$ Ibid. P.149.

${ }^{23}$ Ibid. P. 161.

${ }^{24}$ Попова И. «Детки» Сергея Браткова. Интернет-журнал о фотографии и визуальной культуре Bird in Flight. URL: https://birdinflight.com/ru/ pochemu_eto_shedevr/20160525-kids-masterpiece-shedevr-detki-sergeyabratkova.html 
the practice of implementing femininity in the fashion discourse, it is important to note that despite the steady tradition of designing and cultivating the fashion industry of those feminine images that are oppressive and subordinate in nature, it will be erroneous to consider women as passive victims of the patriarchal power order, whose interaction with fashion marked by suffering and injustice. Developing the thought of Immanuel Kant that in treatment of someone more authoritative [...] and imitate his manners ${ }^{25}$, we note that the willingness to assert oneself through appealing to outwardly formed images that are perceived as consonant with internal ideas about one's own essence lies at the heart of human motivation to actively interact with fashion. A conscious desire to conform to the socially conventional patterns of appearance, behavior, lifestyle, that is, actual femininity is motivated by a universal desire to be recognized, understood and accepted. In the process of public communication, such conformity provides a greater likelihood of a correct interpretation of the symbolic system to which the individual relates.

Fred Davis in a sociological analysis of the fashion phenomenon "Fashion, Culture, Identity" (1992) compares the style of clothing and fashion with a semiotic code that is unstable and changeable: "What a specific garb of last year "informed" can "sound" today completely otherwise and it will also be different from what it "will say" next year" A similar reasoning is presented in the article "Clothing as a medium of communication" (2006) by Cornelia Bohn: "We understand the practice of dressing as situational communication, which is constantly changing"27. Understanding fashion beyond the limits of the subordinate practice of constructing normative femininity patterns makes consideration of the fashion industry as potential space for emancipation. Fashion discourse preserves the paradoxical coexistence of repressive and liberating practices of femininity production: in parallel with the dogmatic prescriptions of the normative implementation of femininity through imitation of fashion patterns, all influential trends of aesthetic pluralism and the individualization of the process of identity formation are observed. The growing need to emphasize one's own uniqueness through clothing is symptomatic against the background of globalization, the gradual erasure of intercultural differences and an unstable political climate, serving as a kind of "visual

${ }^{25}$ Кант И. Сочинения в шести томах. Москва : Мысль, 1966. Т. 6.

${ }^{26}$ Davis F. Fashion, Culture, and Identity. Chicago \& London : The University of Chicago Press, 1992. P. 6.

${ }^{27}$ Bohn C. Clothing as Medium of Communication. Inclusion, Exclusion und die Person. Konstanz. 2006. P.8 
identity metaphor, ${ }^{28}$, which marks the boundaries between the individual and society. According to Elizabeth Wilson, Cheryl Buckley, Hilary Fawcett the modern fashion industry is characterized by an increasing in the potential level of female empowerment. E. Wilson in "Dressed in Dreams. Fashion and modernity"(1985), reflecting on the contradictions of women's encouragement of manifestations of their own individuality and sharp criticism of fashion, however, presents opportunities for asserting her unique style, she notes: "In a society that is constantly in a state of transformation and far from equality, individuals and groups find new ways to express themselves. Moreover, individualism is encouraged, and a divergence of views becomes tolerant to a certain extent" 29 . "Aesthetic pluralism has also become a determining trend in the development of clothing design. Since the late 1960s, there is no more uniform fashion that imperiously dictates its own rules. The lack of strict aesthetic standards, a single fashionable image created enormous opportunities for choice and experiment in the field of clothing design in order to express individuality" ${ }^{30}$.

As an effective strategy for realizing one's own individuality with artistic means of fashion, one can consider the concept of femininity as a masquerade, theorized by Joan Riviere, a follower of Freudian psychoanalysis. In the article "Femininity as a Masquerade" (1929), J. Riviere claims that "femininity as a mask can be appropriated and dressed [by a woman] in order to hide masculinity and avoid punishment if this cover-up is revealed - just like a thief will turn out his pockets to demonstrate that he has not stolen anything. The reader may now ask how I define femininity and how I distinguish real femininity from "masquerade". In my opinion, there is no difference, whether radical or superficial. This is one and the same"31. The grounding of the concept of "masquerade" proposed by Joan Riviere as socially constructed and changing, is an auxiliary mean for hiding the desire for power, it is identified with masculinity, but at the same time this concept indicates about the power potential and the woman's right to create a space for the manifestation of her own personality behind the scenes (hiding under the guise) of convention

${ }^{28}$ Davis F. Fashion, Culture, and Identity. Chicago \& London : The University of Chicago Press, 1992. P. 25.

${ }^{29}$ Wilson E. Adorned in Dreams. Fashion and Modernity. London, New York : Tauris, 2003. P. 203.

30 Наседкина Ю.В. Основные категории эстетики постмодернизма и их воплощение в современной моде. Труды Санкт-Петербургского государственного института культуры. Санкт-Петербург, 2010. № 189. С. 81.

31 Riviere J. Womanliness as Masquerade. The International Journal of Psychoanalysis (IJPA). 1929. Vol. 10. P. 306. 
requirements. A literal reading of the meaning of the mask and masquerade, as well as an appealing to the history of the costume, allows you to find examples of the successful use of the mask as an accessory, which, hiding also reveals the internal desires, motives and intentions of its owner. It is of interest the interpretation of the fashion of bourgeois women to wear masks for attending carnivals and balls in the Paris opera as satisfying their desires for freedom and enjoying entertainment without completely abandoning the usual roles of respectable wives and mothers, mentors for their children, whom attributed them to be J.-G. Rousseau and the dangers of being recognized as immoral: "Although participation in these events [balls and carnivals] did not lead to instant transformations in the roles of bourgeois women, it is obvious that it was under the masks that many of them felt strong. This allowed them to find ways to resist repressive norms of behavior in their home everyday life and create new flexible roles for themselves in their families and their lives"

No less interesting example of empowerment of women thanks to masks is found in Christopher Heyl, who describes the habit of Londoners-women to wear masks that completely cover their faces when visiting parks and theaters in the 17th and 18th centuries. Such a fashion for black masks became a standard accessory, provided respectable women with a sense of privacy and at the same time served as a cover, made them almost invisible in the city, which population is rapidly increasing, inhabiting residents who were no longer good friends, neighbors: "A new masking phenomenon may be defined as an incognito ritual. If you made it clear that you are incognito, then of course people could recognize you, but recognition of your disguise was still expected. This obviously strange, but widespread pattern of behavior shows that the privacy of strangers or people who wanted to treat themselves as strangers was respected"33.

The concept of femininity as a masquerade also serves as an instrument for interpreting the works of such feminist-oriented artists as Cindy Sherman, Theme Ben Tor and Oriana Fox, who transform into various heroines with unfinished stories, juggling images of femininity as masks that have nothing to do with genuine the essence of the created characters. The study of the history and mechanisms of designing femininity by means of

32 Ilan-Alter A. Masked and unmasked at the opera balls. Masquerade And Identities. Essays on gender, sexuality and marginality. London \& New York : Routledge, 2003. P. 150.

${ }^{33}$ Heyl Ch. When they are veiled on purpose to be seen: The Metamorphosis of the Mask in Seventeenth- and Eighteenth-Century London. Masquerade And Identities. Essays on gender, sexuality and marginality. London \& New York : Routledge. 2003. P. 128. 
fashion, as well as consideration of the emancipated potential of fashionable instruments, confirms the socially constructed nature of femininity and pushes us to understand the manifestations of gender performativity in fashion discourse.

The category of performativity, in the scientific discourse of Judith Butler, means "the hopes of a gender entity [which] creates what is postulated as existing outside of it. Secondly, performativity is not a single act, but repetition and ritual, which is triggered by means of true nature in the context of the body, which are partly understood as culturally reinforced time duration"34. For this phenomenon as series of repeating acts, the assertion of gender identity is characterized by the relativity of freedom of choice in the process of gender stylization of the body, predetermined by the sociocultural context of the functioning of the subject. The fashion industry, which is based on the development of gender identities, which are presented as natural, made appearance and behavior models, reflecting the deep essence of the phenomenon of performativity, forming a regulatory and imperious space for the implementation of acts of gender designation. The performative potential of the fashion sphere consists in reproducing the principles of otherness and exclusion, delimiting different groups of consumers, as well as in developing changing images that correspond to a certain philosophical situation and are relevant only in the process of their permanent reproduction. Fashion is the space of theatrical realization of gender, in which clothes serve as a meaningful practice of approving one or another mode of femininity. The clarity of this statement is to undermine the sense of "authenticity" of femininity, which is carried out by various clothing designers from presenting a plurality of versions of the femininity concept. Thus, collections of such fashion houses and clothing brands as Dior, Gucci, Versace, Balenciaga, Chanel, Balmain, Comme des Garcons, Vivienne Westwood represent a kind of cultural performance on the topic of breaking the link between gender and costume. The normative, romanticized femininity of these collections is emphasized traditional, that is reflected through an appealing to classical silhouettes, a rethinking of costumes made of boucle wool, emphasizing the waist with volume belts and the use of delicate, pastel colors, pearls and silver shine. The collection appeals to essential femininity, identified with nature, plants and flowing lines, returning to the ideological program: "After women, flowers are the most divine of all beings. They are so fragile and bewitching, but should be used

${ }^{34}$ Bohn C. Clothing as Medium of Communication. Inclusion, Exclusion und die Person. Konstanz, 2006. 
with great care" 35 . That is why in the Dior spring collection there are almost no trousers, as opposed to numerous fabulous dresses decorated with frills, flowers, lace and embroidery. The autumn collection of recent years, in which femininity enters into a polymorphic dialogue with masculinity with the help of artistic expressiveness, fashionable style, originating from rock music, has become a kind of transformation of retrospective femininity. The costumes of this collection are still based on tight silhouettes, however, clothes colors (sand, brown, terracotta, black) are becoming more active, complemented by the aggressiveness of leather and metal accessories. In particular, there is a noticeable increase in emphasis on female activity and independence, the tireless traveler is in the center of attention, fearlessly overcomes geographical and psychological boundaries. However, the image of an independent woman is complemented by sensuality, daydreaming and the romantization of travel, significantly undermining confidence in the seriousness of her intentions. A radical mix of masculine and feminine stylization stands out the Gucci collection, the presentation of which for the first time in the history of the fashion house included both a female and a male show. In addition, a specific feature of the collection was the mixing of styles, which are difficulty related to each other, the syncretism of gender style attributes, as well as a noticeable tendency to androgyny, which, however, is manifested not in the destruction of differences, but in their eclectic combination without hope for normativity and clarity. The final point in the question of the existence of gender differences in clothes is put by Vivienne Westwood, in whose collections there is no radical separation between male and female, in order to provide the most complete range of opportunities for the individual's choice and self-realization. In addition, in the designer's opinion, this approach helps to reduce waste on the planet, as clothes, the choice of which depends on gender, have more chances to be used.

Returning to the influence of the theory of J. Butler on the understanding of the formative intentions of femininity in fashion discourse, it is advisable to consider the problem of cruelty faced by an individual. The cruelty violates the conventional gender norms of bodily or sexual embodiment, such as derision, restrictions on communication, bullying, exclusion from the public order: "the desire to neutralize the nature of gender arises from a strong desire both to counter normative cruelty that arises from an imaginary morphology of sex and to eradicate common assumptions about natural or

35 Chernikoff L. Maria Grazia Chiuri's First Dior Couture Collection Is a Woodland Fairy Wonderland. Fashion Magazine ELLE. URL: http://www.elle.com/ fashion/news/a42385/maria-grazia-chiuris-first-dior-couture-collection/ 
permissible heterosexuality that are formed through ordinary and scientific discourses of sexuality" 36 . Such cruel treatment is especially noticeable in the perspective of fashionable practices, where the discrepancy between generally accepted gender stylization of the body, that is, the choice of an "inappropriate" costume, an "unsuccessful" combination of various clothing items, a demonstration of luxury items and other manifestations of "bad taste", is severely punished by public opinion.

\section{CONCLUSIONS}

Thus, the sociocultural features of fashion discourse: the desire for imitation and self-expression, regulatory-communicative functionality, the formation of specific bodily experiences and the sexualization of childhood are crucial for understanding the performative nature of femininity in fashion space, making a search for empowerment mechanisms, affirming one's own individuality by means of fashion. The defining features of the formative intentions of femininity in the discourse of fashion and the history of women's costumes are the disciplinary nature of fashion practices and the potential for individualization of the process of identity formation. Appealing to the history of women's costumes opens up numerous practices of educating behavioral inclinations to embody such qualities of normative femininity as seductiveness, passivity, and limited physical mobility by the patriarchal power order. The best reflection of the position of femininity in the creative space of fashion is the image of the mannequin as a suffering cultural subject, thanks to its passive and subordinate position; it acquires a pronounced feminine character, personifying a silent and disempowered object, dressed in accordance with current fashion trends. An important aspect of understanding the specifics of the functioning of the concept of femininity in fashion discourse is taking into account the emancipating potential of this space for representation one's own personality and affirming one's unique style. The implementation of these opportunities is based on the characteristic performativity of gender that promotes the "undermining" of constant stereotypes and the presentation of a plurality of versions of femininity and masculinity.

\section{SUMMARY}

In the context of cultural-historical anthropology, aesthetic and ethical realities of the functioning of fashion institutions, the fashion industry appears on all stages of cultural creation, it is total, super-real and always

36 Батлер Дж. Гендерний клопіт: фемінізм та підрив тожсамості ; пер. Король, Д. Межевікіна, М. Куріна. Київ : Ентіс, 2003. 
inscribed in the presentative space of human life. The connections between fashion and sociocultural conditions are different and are determined by the presence of modern innovations in fashion, which are manifested in the fact that fashion has the exclusive right to formally recognize the priority of the interests of various social groups, which are dictated by the political ideology of the state. The development perspective of the fashion industry is reflected in following rhetorical heritage in the fashion system (R. Bart). At the same time, modern fashion is extremely ambivalent either remaining an art house, or being inspired by a reminiscence space of appealing to ethnic culture, or being an avant-garde space competing with all universals of postmodern fashion aesthetics. Representationalism, eclecticism in the fashionable universe are those elements that modern aesthetics of postmodern carry. Total eclecticism in clothes of a postmodern type is an interesting period, which is determined by searches and allusions in socio cultural space that arise in the context of post-nonconformism the borrowing of Western poetics and its processing, based on the search for authentic national structural harmony, in particular in ethnocultural reminiscences in the fashion industry.

\section{REFERENCES}

1. Bohn C. Clothing as Medium of Communication. Inclusion, Exclusion und die Person. Konstanz, 2006. P. 95-127.

2. Cartwright M.M. Child Beauty Pageants: What Are We Teaching Our Girls? Psychology Today. URL: https://www.psychologytoday.com/ blog/food-thought/201108/child-beauty-pageants-what-are-we-teaching-ourgirls (date of the application: 02.02.20).

3. Chernikoff L. Maria Grazia Chiuri's First Dior Couture Collection Is a Woodland Fairy Wonderland. Fashion Magazine ELLE. URL: http://www.elle.com/fashion/news/a42385/maria-grazia-chiuris-firstdior-couture-collection/ (date of the application: 02.02.20).

4. Cooper R. Fashion and feminism. Australian Feminist Studies. 1987. №. 2: 4. P. 165-176.

5. David A.M. Elegant Amazons: Victorian Riding Habits and the Fashionable Horsewoman. Victorian Literature and Culture. 2002. Vol. 30. №. 1. P. 179-210.

6. Davis F. Fashion, Culture, and Identity. Chicago \& London : The University of Chicago Press, 1992. 227 p.

7. Durham G.M. The Lolita Effect: The Media Sexualization of Young Girls and What We Can Do About It. Woodstock \& New York : The Overlook Press, 2008. 286 
8. Entwistle J. The Dressed Body. Body Dressing. Oxford, New York : Berg, 2001. P. 33-58.

9. Ermine / Encyclopedia Britannica. URL: https://www.britannica.com/animal/ermine-mammal (date of the application: 02.02.20).

10. Heyl Ch. When they are veiled on purpose to be seen: The Metamorphosis of the Mask in Seventeenth- and Eighteenth-Century London. Masquerade And Identities. Essays on gender, sexuality and marginality. London \& New York : Routledge, 2003. P. 114-134.

11. Ilan-Alter A. Masked and unmasked at the opera balls. Masquerade And Identities. Essays on gender, sexuality and marginality. London \& New York : Routledge, 2003. P. 135-152.

12. Johnson B. Riding Side-Saddle. Historic UK. URL: http://www.historic-uk.com/CultureUK/Riding-SideSaddle/ (date of the application: 02.02.20).

13. Linn S. A Royal Juggernaut: The Disney Princesses and Other Commercialized Threats to Creative Play and the Path to Self-Realization for Young Girls. The Sexualization of Childhood. Westport, Connecticut, London : Praeger, 2009. P. 33-50

14. Merleau-Ponty M. Indirect Language and the Voices of Silence. Merleau-Ponty Reader. Evanston, IL : Northwestern UP, 2007. P. 241-282.

15. Riviere J. Womanliness as Masquerade. The International Journal of Psychoanalysis (IJPA). 1929. Vol. 10. P. 303-313.

16. Robinson H. Feminism Art Theory: An Anthology 1968-2014. London : Wiley Blackwell, 2015. 544 p.

17. Toffoletti K. Cyborgs and Barbie Dolls: Feminism, Popular Culture and the Posthuman Body. London : IB Tauris, 2007. 224 p.

18. Wiehe V.R. Nothing pretty in child pageants. Lexington Herald Leader. URL: http://www.kentucky.com/opinion/op-ed/article 44120718.html (date of the application: 02.02.20).

19. Wilson E. Adorned in Dreams. Fashion and Modernity. London, New York : Tauris. 2003. 328 p.

20.Батлер Дж. Гендерний клопіт: фемінізм та підрив тожсамості ; пер. Король, Д. Межевікіна, М. Куріна. Київ : Ентіс, 2003. $223 \mathrm{c}$.

21.Блох И. История проституции. URL: http://lib.rus.ec/ b/111358/read (date of the application: 02.02.20).

22. Бодрийяр Ж. Общество потребления. Его мифы и структуры ; пер. с. фр. Е.А. Самарской. Москва : Республика ; Культурная революция, 2006. 269 с. 
23. Ермилова Д.Ю. История домов моды. Москва : Академия, 2003. $288 \mathrm{c}$.

24. Кант И. Сочинения в шести томах. Москва : Мысль, 1966. T. $6.743 \mathrm{c}$.

25. Манокин М.А. Ювенилизация современного общества: культурологические аспекты. Общество. Среда. Развитие (Terra Humana). 2012. № 3. С. 77-81.

26. Наседкина Ю.В. Основные категории эстетики постмодернизма и их воплощение в современной моде. Труды СанктПетербургского государственного института культуры. СанктПетербург, 2010. № 189. С. 81-87.

27. Попова И. «Детки» Сергея Браткова. Интернет-журнал о фотографии и визуальной культуре Bird in Flight. URL: https://birdinflight.com/ru/pochemu_eto_shedevr/20160525-kidsmasterpiece-shedevr-detki-sergeya-bratkova.html (date of the application: 02.02.20).

Information about authors: Gaznyuk L. M., Doctor of Philosophical Sciences, Professor, Head of Department of Humanities Kharkiv State Academy of Physical Culture 99, Klochkovska Str., Kharkiv, Ukraine

Semenova Yu. A., Candidate of Philosophical Sciences, Associate Professor, Professor at the Department of Humanities Kharkiv State Academy of Physical Culture 99, Klochkovska Str., Kharkiv, Ukraine 